\title{
Entre Príapo E Dioniso: Reflexões SOBRE A MASCULINIDADE
}

Luciano Lima Oliveira1

Laéria Fontenele2

\section{Resumo}

No caminho até a masculinidade o menino deve ultrapassar a posição feminina em relação ao pai, que implica a castração como premissa. $O$ recalque dessa posição desejante retorna na cultura pelo ódio às mulheres e a todo sujeito suposto encarnar o feminino. $O$ avanço deste último na cultura, junto com o declínio dos referentes patriarcais constituem para os homens uma ameaça à masculinidade. Um dilema se insinua: recorrer a Príapo, deus itifálico, ou aproximar-se de Dioniso, isto é, do feminino. Este artigo discute essas duas posições à luz da psicanálise e do teatro grego, sobretudo da figura de Héracles, herói símbolo da hipermasculinidade

Palavras-Chave: Psicanálise; Masculinidade; Feminilidade; Príapus; Dionísio.

\footnotetext{
1 Doutor pela Université Côte d'Azur - Nice - França. Doutor pela Universidade Federal do Ceará (UFC). Mestre em psicologia pela Universidade Federal do Ceará (UFC). Psicólogo do Hospital Walter Cantídio. E-mail: lucianoldeoliveira@yahoo.com.br. ORCID: http://orcid.org/0000-0001-6387-9428 2 Professora Titular da Universidade Federal do Ceará. Coordenadora do Laboratório de Psicanálise da UFC. Membro da Academia de Letras e Artes do Nordeste. Doutora em Sociologia. E-mail: laeria@terra.com.br.ORCID http://orcid.org/0000-0003-1356-7631.
} 


\section{INTRODUÇÃO}

Durante séculos, especialmente após o advento do patriarcado, os homens acreditaram que para ser homem, "homem de verdade", era preciso manter sob seu domínio a feminilidade. Qualquer tentativa de emancipação do feminino, estivesse ele representado pelas mulheres ou por outros homens, era sentida como uma ameaça à masculinidade. Vigarello (2013) nos conta, por exemplo, que já no final da renascença, o rei James I da Inglaterra, até tolerava que seu filho, futuro rei, fosse um homem doce, manso, não afeito à violência. Por outro lado, havia duas coisas que ele, como homem, deveria estar sempre apto a demonstrar: a capacidade de domar seu cavalo e dominar sua mulher. Isso ilustra bem a estreita relação entre a masculinidade e o que Pommier (2016, p.68) chama de um "desejo desenfreado de dominação", que a caracterizaria. Tal desejo encontrou na organização social patriarcal as condições mais apropriadas para sua realização. A tal ponto que, legalizada e legitimada, a dominação exercida pelos homens sobre todos os que encarnavam o feminino inscreveu-se na cultura sob a forma de um poder que se pretendia absoluto e natural.

Por que a feminilidade precisa ser dominada, que ameaça ela representa para a masculinidade? Trata-se de uma ameaça que vem do exterior ou ela procede, antes, do interior de cada homem? E, finalmente, como manter a feminilidade à distância $\mathrm{e}$ sob domínio, quando, atualmente, os semblantes fálicos patriarcais da masculinidade se encontram em franco declínio? Tentar discutir essas questões constitui o objetivo deste artigo. Para isso, nos valeremos da noção psicanalítica de bissexualidade psíquica e de alguns elementos da tradição grega, especialmente, a mitologia, a literatura e o teatro.

\section{A Bissexualidade Psíquica e o Recalque Da Feminilidade No Caminho ATÉ A MASCULINIDADE}

A concepção de uma disposição bissexual é útil a Freud não apenas para tentar abordar a masculinidade e a feminilidade, mas também para teorizar sobre a escolha de objeto. Com a noção de bissexualidade psíquica, da qual Freud nunca abriu mão, aprendemos que pelo fato do ser humano não ser determinado por nenhum saber instintivo, não há nem masculinidade nem feminilidade exclusivas.

Psicanálise \& Barroco em revista | v.17, n. 3 | dezembro de 2019 
A disposição bissexual do indivíduo aparece de modo cristalino nas fantasias histéricas. Freud (1908) chama atenção para o fato de a investigação psicanalítica do sintoma histérico apontar o papel desempenhado, em sua composição, por fantasias masculinas e femininas; engendradas por exigências de satisfação pulsionais de caráter ativo e passivo. É o que Freud nos indica através do exemplo que nos fornece da mulher que com uma mão segura o vestido contra o corpo, ocupando o lugar de objeto de uma investida sexual, e com a outra sinaliza querer se livrar da roupa, identificando-se com o homem violador.

Assoun (2006, p. 38), observa que se de um lado atividade e passividade constituem um par volátil é "mediante essa metáfora material que a 'doutrina da bissexualidade' começa a encontrar sua conexão com a 'doutrina pulsional'. Ativo e passivo se convertem, assim, em valiosos operadores metapsicológicos, que permitirão a Freud pensar a masculinidade e a feminilidade em suas articulações com os destinos da pulsão. Articulados, assim, à gramática pulsional, o masculino e o feminino estarão presentes em diversas formações do inconsciente - como o sintoma e a fantasia -, apontando o modo pelo qual o sujeito se situa diante da castração.

A problemática do masculino e do feminino, tal como a encontramos na obra freudiana, permite-nos inferir que a relação entre eles é menos de exclusão que de combinação; o que, de certa forma, aproxima Freud das concepções sobre masculinidade e feminilidade presentes em tradições antigas, sobretudo gregas, como veremos mais adiante. Isso nos possibilita pensar que um mesmo indivíduo pode ocupar uma posição masculina frente a um objeto e feminina em relação a outro; ou até questionarmos se, em relação ao mesmo objeto, determinado sujeito não poderia transitar de uma posição masculina a uma feminina e vice-versa.

Sobre isso há elucidativas passagens em alguns textos freudianos. Em "Algumas consequências psíquicas da diferença sexual anatômica", por exemplo, Freud (1925) se dirige aos feministas de ambos os sexos, assegurando-lhes que:

[...] também a maioria dos homens permanecem muito aquém do ideal masculino e que todos os indivíduos humanos, em virtude de sua disposição bissexual [...] combinam em si características tanto femininas como masculinas, de modo que a masculinidade e a feminilidade puras não passam de construções teóricas de conteúdo incerto (FREUD, 1928, p. 2902) 
Já em "A sexualidade feminina", Freud (1931) afirma que o trânsito da passividade para a atividade é um fato inerente à vida anímica. Ele observa, entretanto, que a passagem da passividade para a atividade não acontece do mesmo modo, com a mesma eficácia, para todos; e que dessa variabilidade - ponto importante - "pode-se deduzir a força relativa das tendências masculinas e femininas que deverão se manifestar em sua vida sexual" (p. 3084). Finalmente, em "A feminilidade", Freud (1933, p.3165) afirma: "Dizemos, pois, que um ser humano seja macho ou fêmea, se comporta de modo masculino em tal ponto e feminino em tal outro".

A disposição bissexual desempenhará um papel importante na constituição da masculinidade, evidenciando que o tornar-se homem comporta uma complexidade, à qual mesmo Freud, por vezes, não pareceu ter dado a devida atenção; tratando a assunção da masculinidade como algo destituído de interesse investigatório. A influência da bissexualidade a que nos referimos acima se fará sentir de modo inequívoco no desenrolar do complexo de Édipo.

Efetivamente, com Freud (1923), aprendemos que no caminho conducente à assunção da masculinidade, o menino não apenas deve renunciar ao gozo com a mãe, mas também a ocupar uma posição feminina, passiva, em relação ao pai, desejando ser a causa de seu desejo. Assim, podemos inferir que o feminino, ou mais precisamente, a posição feminina não é, então, um mero acidente de percurso no Édipo do menino, mas uma posição desejada por este; e, mais ainda, em relação ao pai.

Contudo, por equivaler à uma feminização, ela atualiza a ameaça de castração e deve, por isso, ser recalcada. Desse modo, poderíamos admitir a hipótese de que o feminino que os homens sempre buscaram dominar e manter à distância, na tentativa de, assim procedendo, se assegurarem de sua masculinidade, não se localiza, de saída, no exterior. Esse feminino, que para o homem - diferentemente da mulher - é sempre fonte de um horror associado à angústia de feminização, de castração, é o que ele se vê compelido a recalcar no processo de construção da masculinidade.

Para Freud (1914, p. 2002), é "a virilidade narcísica dos genitais", um amor pelo falo, que agiria como motor do recalque. $O$ temor da castração aparece aí como o agente que deverá levar o menino a renunciar às duas modalidades de satisfação que Ihe são disponibilizadas no complexo de Édipo; uma vez que ambas, como afirma 
Freud (1924), implicariam a perda do pênis: a primeira - substituir o pai para ocupar seu lugar junto à mãe, como punição; a segunda - substituir a mãe para se fazer amar pelo pai - como premissa.

Para ser homem, viril, seria necessário, portanto, recalcar, repudiar e reprimir a própria feminilidade. Mas pelo fato mesmo de ter sido desejada e, por isso, recalcada, a feminilidade insiste em fazer retorno. O desejo, como bem o sabemos, não se extingue por ter sido recalcado; ele se torna mesmo ainda mais reivindicador.

Quando as exigências do recalcado podem ser negociadas pela intermediação do simbólico, a satisfação pulsional pode ser encaminhada pela via do sintoma, do sonho, e até da arte. Por outro lado, como bem observa Pfauwadel (2017, p.6), "ali onde o semblante fálico não regula mais tão bem o gozo pelo simbólico nós assistimos ao retorno no real de uma virilidade grotesca, machista e belicosa, que se mostra de maneira sempre mais desinibida". Trata-se aí, segundo o autor citado, do desencadeamento de um ódio violento contra a feminilidade em resposta "à desconstrução dos referenciais tradicionais da masculinidade". Essa tem sido, de modo geral, a maneira atual de se encaminhar o horror ao feminino e mantê-lo distante.

Pelo exposto, e nos apoiando em Pommier (2016), levantamos a hipótese de que o ódio acima referido denuncia o horror do homem relativo a seu próprio desejo de feminilidade; que o angustia e o ameaça desde o interior. A repressão e a violência contra todos os que encarnam o feminino poderiam ser pensadas como o resultado de uma projeção sobre eles do desejo do homem de ser desejado pelo pai. É contra essa feminilidade que a masculinidade será construída.

Tal construção é sempre precária, uma vez que, como já dissemos, ela é constantemente ameaçada pelo retorno do desejo recalcado. Isso nos faz recordar o mecanismo da fobia, que Freud $(1914,1915)$ descreve em termos de "construções protetoras", as quais precisam ser sempre reforçadas e ampliadas a cada vez que as exigências pulsionais se fazem sentir. Interessante sublinhar que para Freud (1915), o objeto fóbico é, de fato, um substituto de outro objeto, sobre o qual o investimento libidinal recai, a saber, o pai. Nesse sentido, revela-se bastante apropriado o termo "homofobia", utilizado para caracterizar as construções protetoras - cada vez mais 
amplas e violentas -, pelas quais, na atualidade, os homens buscam se defender da angústia de feminização.

É a uma tentativa violenta de restauração do falo como significante-mestre, agenciador dos laços entre os sexos, que assistimos atualmente. Parece-nos, assim, que na tentativa de fazer frente à emancipação cada vez maior do feminino, enquanto associado ao arrebatamento, ao que está além das amarras fálicas e, por conseguinte, a uma maior liberdade em relação à normas e aos tabus, os homens se lançam na tarefa de restaurar o falicismo patriarcal; desde o qual acreditam que sua masculinidade pode ser afirmada e protegida pela via da realização do desejo desenfreado de dominação. Para estes homens, poderíamos dizer que ao avanço de Dioniso, é preciso recorrer a Priapo.

Todavia, como veremos a seguir, Priapo e Dioniso, na tradição grega, guardam mais proximidade entre si do que muitos homens talvez possam imaginar ou desejar. Tal proximidade, que reflete um laço menos de oposição que de combinação entre masculinidade e feminilidade, foi largamente explorada pela literatura e pelo teatro gregos, em relação aos heróis, sobretudo Héracles. Este, símbolo incontestável de uma hipervirilidade, carrega sempre uma marca, um signo da feminilidade, ao menos de sua época. O que devemos sublinhar é que tal marca, indicadora de uma vulnerabilidade e de uma fragilidade próprias ao herói, nunca atrapalha ou põe em risco sua masculinidade.

\section{Entre Dioniso e Príapo, o Phallus}

Segundo nos informa Daniélou (1993), no início do período neolítico, instaurou-se, desde a Índia até o extremo Ocidente, cultos consagrados ao phallus. Não deixa de ser interessante observar que a época histórica acima aludida corresponde à sedentarização da espécie humana, que passa, então, a se fixar na terra, próxima aos rios, vivendo menos da caça que da agricultura e da criação de animais em cativeiro. Esta última atividade, segundo a hipótese de Dupuis (1989), teria dado início à lenta apreensão do papel do sêmen e, por via de consequência, do macho e do homem na procriação. 
O reconhecimento do papel do pênis e do sêmen na procriação é atestado, conforme Daniélou (1993), por vários desenhos rupestres em que, ao contrário daqueles pertencentes ao período paleolítico, a figuração do pênis ereto, representando o phallus como potência criadora, ocupa uma posição central em relação às representações do feminino. É o caso de um desenho encontrado no sítio arqueológico de Audoubert, nos Pirineus, contendo a imagem de um phallus do qual um jato líquido se desprendia.

A partir do período Magdaliano (13000-6000 a.C.) os cultos ao phallus se multiplicam. Os pesquisadores encontraram registros da veneração a deuses itifálicos (aqueles representados com um pênis ereto) nas civilizações egípcia, grega, romana, celta indiana, dentre outras. No Egito, era prestado culto ao pênis amputado de Osíris, deus da vegetação; na Grécia antiga o phallus era venerado em honra aos deuses Hermes e Dioniso. O primeiro era associado à fertilidade e o segundo, aos ciclos vitais. Já em Roma, era costume os generais que triunfavam nas guerras portarem amuletos representando o phallus. E os celtas, por seu turno, veneravam deuses itifálicos que também eram representados com um chifre.

Dentre os povos que o adotaram o culto ao phallus, os hindus foram aqueles em cuja cultura, segundo os estudiosos, o referido culto nunca deixou de ser praticado. A divindade Shiva, deus itifálico, cuja personificação era atribuída ao touro, tinha como símbolo o phallus e era, assim como todas as divindades itifálicas, o deus da fertilidade, da criação (Daniélou, 1993).

Ainda seguindo as pesquisas do autor supracitado, encontramos a explicação de que linga, termo que em sânscrito significa signo, é a palavra utilizada para designar o pênis. Linga é tudo o que serve para distinguir, para diferenciar a natureza de alguma coisa. Shiva, o Ser Absoluto, o qual, como dito há pouco, era simbolizado pelo phallus, não tem sexo e só pode se fazer perceber através de sua criação. Conforme assinala Daniélou (1993, p.23): "O Linga ou phallus, fonte de vida, é a forma através da qual pode ser evocado o Ser Absoluto do qual o mundo saiu". Desse modo, tal como se encontra em um dos cantos hindus dedicados ao homem cósmico, cultuar o phallus não é cultuar o pênis: "Venerando o Linga, nós não deificamos um órgão físico, nós reconhecemos simplesmente uma forma eterna e divina manifestada no microcosmo. O órgão humano é a imagem do emblema divino, da forma causal, 
eterna do Linga, presente em todas as coisas" (Purusha Sukta, apud Daniélou, 1993, p.23). O homem, nos diz o mesmo autor, "é apenas o 'portador do falo'[...]. A noção de deus-pai é uma transposição puritana do falo divino. O pai é aquele que derrama a semente no receptáculo" (p.36).

Tal correspondência entre o falo e o fluxo vital nos permite inferir o papel não apenas do masculino, mas também da paternidade, na formação da cultura. Conforme Maurano (2013):

\begin{abstract}
Podemos pensar que o saber relativo às operações do phallus é o que diz respeito à força que a natureza empresta ao homem para que ele, sobrepondo-se a ela, passa a criar cultura. Ou seja, recrie o mundo, fazendo dele mesmo um criador. Daí ser creditada à criação da cultura a falicidade relativa à posição masculina. Talvez por isso a grande maioria (senão a totalidade) das culturas civilizadas, pelo menos no Ocidente, seja patriarcal (p. 319, grifo da autora).
\end{abstract}

A associação das divindades itifálicas com a vegetação, com a fertilidade e a fecundação encontrou no deus Priapo uma de suas mais notáveis expressões. Filho de Afrodite e Dioniso, Priapo nasce com uma deformidade incorrigível: um enorme pênis condenado a permanecer eternamente ereto. Essa desdita é o resultado da punição que Hera, deusa da fidelidade conjugal e esposa de Zeus, faz cair sobre Afrodite, por conta da promiscuidade desta última, inclusive com Zeus. Por não suportar a deformidade de seu filho, Afrodite o abandona no campo. Priapo é encontrado e criado por pastores, o que corrobora com o caráter humilde de que ele é revestido e que estará presente também em muitos de seus adoradores.

A versão que atribui a paternidade de Priapo a Dioniso é coerente com o fato de que a representação do primeiro integrava as falofórias, procissões que eram parte do culto ao segundo. Nelas, um sacerdote, o falóforo, seguia à frente do cortejo, carregando um enorme falo até o local onde o culto a Dioniso teria lugar. Segundo Brandão (1992), nas falofórias as pessoas usavam máscaras, dançavam e, ao final, assistiam a concursos de comédia e tragédia na presença de uma grande estátua do deus da metamorfose e do entusiasmo. Por essa razão, o culto a Dioniso está intimamente ligado ao início do teatro grego.

O culto a Dioniso não foi aceito tão facilmente na pólis grega, sendo o aludido deus considerado "o menos 'político' dos deuses gregos" (p.125). Conforme sublinha Brandão (1992), "o homo dionysiacus [...]em êxtase e entusiasmo, comungando com a imortalidade, tornava-se anér, isto é, herói, um varão que ultrapassou o métron, a 
medida de cada um" (p.132, grifo do autor). Essa ultrapassagem do métron tinha, para os adeptos de Dioniso, o sentido de um abandonar-se ao deus, a uma comunhão com ele, expressa no estado de êxtase. Este último implicava, por conseguinte, um sair de si mesmo, um fora de si, compatível com uma maior liberdade relativa aos tabus e à lei; não passível de ser experimentada pelos seguidores de Apolo. Devido a seu caráter de desmesura (hybris), de arrebatamento, Dioniso representava uma ameaça considerável de ruptura das ordens social, política e patriarcal regidas pela doutrina apolínea do comedimento, da disciplina, da retidão. Nas palavras de Brandão (1992, p.137, grifo do autor): "Uma divindade assim tão próxima e integrada no próprio homem, um deus tão libertário e 'politicamente' independente, não poderia mesmo ser aceito na pólis de homens e de deuses tão apolineamente patrilineares e tão religiosamente repressivos".

Pelo exposto, não estamos distantes, com Dioniso, do campo daquilo que em psicanálise podemos entender por feminino, que aponta para um além da ordem fálica. Sobre isso, Maurano (2018) observa que a noção de feminino se articula a esse além do universo fálico, o qual é "sempre referido à plena potência vital, à retidão, à virilidade. Este mais além[...] articula-se à noção psicanalítica de feminino e ao gozo que the é próprio, e que é diferente do masculino. Nele o que se afirma não é o si mesmo, mas a entrega, a comunhão com o todo e o êxtase advindo dessa entrega"3. Assim, Priapo, em sua deformidade fálica, signo de uma hipervirilidade, é filho do deus cujo culto pretendia dar lugar justamente ao ultrapassamento do masculino e do falicismo.

Embora Priapo esteja frequentemente associado a uma máxima potência viril, o que implicaria, portanto, excluir qualquer alusão ao feminino, os relatos dos historiadores, bem como os achados arqueológicos, especialmente as pinturas e esculturas encontradas na Grécia e em Roma, sugerem que o feminino não estava ausente de Priapo. De fato, Oliva Neto (2006) nos conta que no período helenístico, entre os séculos III e II a.C., Priapo era representado às vezes como uma figura hermafrodita, bissexuada, às vezes portando traços característicos da feminilidade da

3 Conferência "A arte e alma barroca brasileira", proferida em 29/11/2018, no Ciclo de Conferências "O barroquismo brasileiro", promovido pela Academia Brasileira de Letras. Disponível em https://www.youtube.com/watch?v=53_tTbPi2Os. 
época. Reunindo, assim, em Priapo, elementos do masculino e do feminino, os gregos pareciam indicar a totalidade cósmica do culto orgiástico de Dioniso, do qual Priapo se origina, garantindo, assim, a mesma proteção à fecundidade, que seu pai garantia.

A referência ao caráter protetor de Priapo, aponta para outra função do falo na cultura grega: seu caráter apotropaico, isto é, seu poder de afastar influências maléficas. Este aspecto do falo não se restringiu à Grécia e à Roma antigas, onde esculturas fálicas eram erigidas nos portos, nas estradas e nos edifícios públicos. Em nossos dias, amuletos fálicos, como a figa, ainda fazem parte de nosso cotidiano. Assim, não necessariamente a representação direta de um pênis em ereção, mas diversos outros elementos que o simbolizam, associam-se à função protetora do falo. Interessante notar que, sobre isso, Freud (1922, p.2696) afirmara que "mostrar o pênis - ou qualquer de seus sucedâneos - significa dizer: 'Não te temo, te desafio; tenho um pênis.' Eis aqui, pois, outra maneira de intimidar o espírito maligno".

A dimensão apotropaica e intimidadora do falo, na figura do deus Priapo, adquire maior relevo quando este deus passa a ocupar também o espaço privado da pólis, isto é, as hortas, os pomares, os jardins. Nestes espaços reencontram-se tanto a função de garantir o fluxo vital expresso na exuberância dos frutos e da vegetação quanto o de proteger a riqueza, os bens, a propriedade daquele que o instala na frente de sua casa. Conforme Oliva Neto (2006):

[...] deus passa a guardar um terreno cercado que é de um só, o patrão, cujos bens protege por meio de uma fala ameaçadora: Priapo, o deus fálico, o deus-falo, então fala, fala no jardim. Priapo faz-se falastrão e, subordinada, sua fala torna-se tanto mais inflada quanto menor é seu poder. Sua falação, as penas que ameaça [...] sustentam-se no membro ereto [...]. O Priapo do cercado é guarda e sua arma é o membro enorme e, ao contrário do Priapo hermafrodita ou efeminado dos espaços públicos, ele agora é necessariamente supermasculino e itifálico (p.88-89).

Digno de nota esse deslocamento que se opera sobre o falo no seio da cultura. Ainda mais pelo fato de que o poder fálico passa a guardar uma estreita relação não tanto com o visível - sua imagem - mas com a fala. O falo então é deslocado do coletivo para o particular, do público para o espaço íntimo, do olhar para a palavra. Nesse deslocamento ele perde paulatinamente os traços efeminados em favor da hegemonia dos traços masculinos, condensados no pênis ereto. Outro ponto a sublinhar é que a ameaça, a "mal-dição" que ele profere, isto é, a expressão de seu poder - geralmente através de epigramas -, encontra seu suporte na posse do 
membro viril sempre ereto, em permanente estado de prontidão. Curiosamente, conforme nos informa o dicionário Aurélio, outro sentido para prontidão é pindaíba, ou seja, falta de dinheiro, dureza. Dizer que se está duro, é confessar sua falta, um déficit fálico. Quanto mais duro está um homem, mais faltoso e, de certa forma, desfalicizado, ele se revela. Enfim, a citação acima não deixa de nos remeter ao modo pelo qual o falo será teorizado na psicanálise, notadamente por Lacan: no domínio da palavra, ou melhor, do significante.

A entrada de Priapo no jardim também enlaça o falo a um elemento que será bastante explorado na comédia, tanto no teatro quanto na poesia: o riso e o ridículo. Este último, inclusive, segundo Lacan (1957-1958/1999), está presente na fanfarronice pela qual tantos homens expressam sua virilidade. Essa dimensão foi magistralmente explorada por poetas gregos e romanos através de um gênero literário conhecido como priapéia.

A priapéia, segundo Oliva Neto (2006), tem origem nos epigramas, isto é, no costume de se fazer inscrições em objetos e túmulos, por exemplo. No caso dos primeiros, o epigrama servia para designar tanto o proprietário quanto o artesão que o criara; quanto aos túmulos, as inscrições poderiam indicar o nome do morto, suas virtudes ou alguma dedicatória específica. O priapeu, nos diz Oliva Neto (2006, p.83) "é o poema em que a presença de Priapo é manifesta ou de tal modo presumida que deixar de nomeá-lo não impede reconhecê-lo". Como exemplo, podemos citar um epigrama do século III a.C., encontrado em uma lápide, na região da Sicília, em que Priapo fala aos passantes em nome do proprietário de um pomar: "Rúbrio de Samos/ me pôs a vigiar esta e aquela direção/ordenando abster-se os que moram na cidade/ e abster-se os que moram junto ao Ácis de/ roubar-lhe as frutas; assim eu mostro, ereto/ este enorme pênis aos ladrões" (OLIVA NETO, 2006, p. 24-25).

A dessacralização do falo, que corresponde ao afastamento do falicismo relativamente ao contexto religioso, é o que responderia pelo rebaixamento e a risibilidade da qual Priapo passa a ser objeto, e que se manifesta nas falas que, na poesia priápica, Ihe são atribuídas. Sobre esse ponto, Oliva Neto (2006) afirma de modo elucidativo que:

Assim, no discurso de Priapo desses poemas, o próprio teor sexual e obsceno, a inadequação entre o caráter pretensamente numinoso e a subserviência a um patrão, somada à dissociação manifestada no 
recrudescimento do autoritarismo falicamente ameaçador na razão inversa da decrescente autoridade, fazem que a fala de Priapo fálico, guardião dos jardins, se torne deturpada, inepta e, portanto, risível (p.89).

Fazendo um paralelo com a atualidade, nossa época, como dito anteriormente, é marcada pelo declínio de uma masculinidade tradicionalmente construída em função do poder patriarcal. Diante de tal declínio, alguns homens apelam para o recrudescimento de posturas violentas na tentativa de reestabelecerem a hegemonia do falo na cultura. Assim procedendo, não estariam eles, de certa forma, convocando a função apotropaica deste último, no sentido de afastar qualquer ameaça à masculinidade, que o feminino é sempre suposto representar?

Tanto a priapéia quanto a invenção do teatro grego nos mostram, contudo, a possibilidade de outras formas de lidar com as diferenças entre Apolo e Dioniso, entre o fálico e o feminino. A poesia priápica e o teatro constituíram, pois, dois espaços em que o homem grego podia lidar com o masculino e o feminino, as forças da cultura e da natureza sem recorrer ao ódio. Quanto a isso, Maurano (2018) nos esclarece que:

\footnotetext{
Os gregos antigos, ao inventarem o teatro, arranjaram um jeito de acolher a dimensão atroz da vida sem sucumbir, sem precisar recalcá-la. Assim, ao invés de meramente recalcarem o bárbaro para constituir a cidade, deramIhe expressão artística. [...] Mas para conseguirem essa proeza, com Nietzsche bem o ressalta em "O nascimento da tragédia", transfiguraram o horror através da música e da beleza. E ainda jogaram com a comédia, que comparecia no final da tragédia. Ao final, resta mesmo é rir4.
}

As palavras da autora nos advertem que, embora a pólis grega se constituísse em torno do masculino, deixando à margem o feminino e as mulheres, a cultura grega reservava espaço, em sua literatura e no teatro, para uma espécie de reunião ou de troca entre masculino e feminino.

\section{O Masculino e feminino No Homem Grego: A Bissexualidade Em HÉRACLES}

Loraux (1989) desenvolve de maneira bastante elucidativa essa capacidade dos gregos de reservarem no seio mesmo da cultura um espaço para a expressão do feminino. A autora nos lembra que em toda tradição indo-europeia, da Índia à Grécia, podemos observar trocas contínuas entre o masculino e o feminino tanto na religião 
quanto nos mitos. Trocas que, segundo a autora, se evidenciam, por exemplo, nos trajes femininos de Arjuna, herói da epopeia hindu, nos vestidos de Héracles, ícone da hipermasculinidade, e na pele macia e suave dos guerreiros da llíada.

Ainda conforme Loraux (1989), o registro dos intercâmbios entre os sexos balizava-se, sem se reduzir a elas, pela combinação e pela inversão. A primeira localizava-se na dimensão corporal, na bissexualidade que comparece tanto no discurso médico hipocrático quanto na tradição mitológica. A inversão, por seu turno, destacava-se no contexto dos cultos religiosos e iniciáticos, nos quais homens e mulheres travestiam-se com os signos da feminilidade e da masculinidade. Assim, por exemplo, os jovens que se encontravam às vésperas de aceder à idade viril, bancavam a mulher durante certo tempo; e as mulheres espartanas, recém-casadas, cortavam os cabelos para, masculinizando-se, receberem os maridos. Entretanto, conforme adverte a autora que ora seguimos, reduzir o tratamento dado pelos gregos à diferença sexual ao imaginário relativo à inversão é desconhecer que os ritos gregos antigos eram marcados por uma inegável dissimetria, onde os homens eram privilegiados. Uma boa ilustração disso é, mais uma vez, o teatro.

Loraux (1989) chama a atenção para o fato de que o teatro era o lugar por excelência da inversão. Entretanto, por não ser senão homens, cidadãos, cuja virilidade não era posta em dúvida, que tomavam parte nas peças, a dissimetria da inversão era patente. Nas palavras de Loraux: "[...]como não refletir sobre o jogo do real e da ficção quando um ator que assume um papel feminino deve interpretar a mulher que se disfarça em homem?" (p.14). O teatro mantém, assim, uma relação estreita com a feminilidade, a começar, nos lembra Loraux, pelo próprio deus que o tutela, o andrógino Dioniso. Em vista disso, conclui a aludida autora: "[...] o teatro usa do feminino para imaginar um modelo mais completo do si mesmo masculino. [...]representar o outro é o que abre a identidade masculina do cidadão às emoções frequentemente banidas do terror e da piedade" (p.14).

É justamente na figura de Héracles, herói que na mitologia costuma ser o símbolo de uma supermasculinidade, que encontramos, de modo exemplar, a combinação e até a inversão entre o masculino e o feminino.

Conforme observa Loreaux (1989), diversos autores se empenharam em sublinhar as ambivalências do filho de Zeus, dentre as quais destacam-se os 
seguintes pares antitéticos: civilizado-bestial, livre-escravo, são-louco. A essa lista, Loreaux propõe que seja acrescentado o par viril-feminino. Para Loreaux, com Héracles, nós estaríamos diante de "uma das figuras gregas da feminilidade no homem grego" (p.149).

A fim de demonstrar sua tese, a autora discute ao longo de várias páginas a estreita relação que o filho de Zeus mantém com os atributos e os signos que para os gregos apontavam para o campo do feminino. Não nos ocuparemos de todos os elementos que constituem o objeto de investigação de Loreaux, optando por destacarmos alguns que nos parecem mais apropriados a pensar certos tabus relativos ao ser homem, que, de certo modo, ainda se fazem presentes em nossa cultura: a expressão de sentimentos de medo e de dor, isto é, o sofrer, e a subjugação a uma mulher.

Loreaux nos recorda que se por um lado o discurso grego, conforme o mito de Tirésias, não admitia para os homens a possibilidade de conhecerem o gozo feminino, por outro, ele os autorizava o acesso a outro elemento reservado ao domínio do feminino, qual seja, o sofrimento. Para além dos emblemas da feminilidade dos quais a figura de Héracles fora paramentada - a adoção do peplo, a indumentária feminina por excelência, é o exemplo maior -, a experiência do sofrimento que o herói conhece em sua agonia constitui um modo de "viver a feminilidade em seu corpo" (p.149).

O sofrimento de Héracles, através do qual se chamava a atenção para a báscula da virilidade, pode ser observado de maneira dramática tanto no episódio de seu enlouquecimento quanto de sua morte. Deve-se ressaltar, todavia, que ambos os acontecimentos pertencem a duas peças trágicas distintas, sendo o primeiro do "Héracles" de Eurípedes e o segundo de "As traquínias", de Sófocles. Essa observação é pertinente, haja vista que a virilidade de Héracles não é apresentada da mesma maneira nas duas tragédias. Como bem pontua Arrowsmith (1956/2014), se na peça de Sófocles todos os elementos da tradição, que marcavam a virilidade do herói com os signos da brutalidade, do adultério e das proezas sexuais, foram preservados, o Héracles de Eurípedes rompe com esse padrão. Héracles nos é apresentado como um marido fiel, filho devotado e pai amoroso. Não poderíamos pensar que tal ruptura implicaria também um deslocamento dos semblantes da 
masculinidade que a tradição havia consagrado a Héracles? Essa hipótese nos parece estar em consonância com o questionamento que Arrowsmith (1956/2014 p.170) levanta. Diz o crítico: "Que audiência, especialmente uma grega, teria reconhecido o austero herói cultural recebido da tradição naquele Héracles alquebrado, quase caseiro, tentando conter as lágrimas?".

A loucura de Héracles, nos conta Eurípedes (480-406 a.C./ 2014), é mais uma das inúmeras expressões do ódio de Hera, esposa de Zeus, ao herói. Este, desde sua infância é alvo de sua ira ciumenta, perseguindo-o implacavelmente por ele ser o fruto do amor de Zeus e Alcmena. Em represália ao adultério deste último, Hera faz com que Héracles, enquanto brincava com seus filhos, seja tomado pela fúria, que o leva a lançar mão de seu armamento e assassinar sua progenitura e sua esposa. A dramática reação de Héracles, logo que ele percebe o que fizera, nos põe diante da queda do herói, que inundado por terrível angústia se recolhe em pranto inextinguível ao interior da casa, cobrindo o rosto com o peplo, para escapar ao olhar do outro. É assim que Teseu o encontra, "pluricombalido e plurierrante", como o descreve Anfítrion, seu pai. Teseu, voltando-se para Héracles, lança-Ihe a seguinte exortação: "Falo contigo, tu que estás sentado/ num sítio de dar dó/ descobre o rosto e encara o amigo! (versos 1214-1216) [...] Mira, em pé, / o olhar de todos: nobre não é quem/ renega o fardo divo, mas suporta-o" (versos 1226-1228). Mas Héracles não consegue e lhe diz: "Provei inúmeros padecimentos, / sem nunca me desviar, sem derramar/ um pranto, sem imaginar que um dia/ o jorro lacrimal me inundaria" (versos 1353-1356). Finalmente, à injunção de Teseu: "Já basta de chorar! Em pé, infeliz!" (verso 1394), o herói responde: "Eu não consigo: as juntas se enraízam" (verso 1395).

Conforme destaca, Loreaux (1989), podemos observar no Héracles de Eurípedes elementos que apontam para a presença do feminino no herói. Um desses elementos é o próprio ato criminoso que ele, enlouquecido, comete. $O$ assassinato dos filhos era, com efeito, atribuído à mulher, representando uma das figuras do feminino. Disso Medéia, a esposa de Jasão, e Procne, mulher de Tereu, constituem dois bons exemplos. Em sua fúria delirante, matando seus filhos, "Héracles igualou sua desgraça a das mães assassinas[...]" (p.149). Outro ponto sublinhado pela autora acima citada é o pranto inconsolável ao qual Héracles se entrega. A expressão da dor, como nos lembra Héritier (2012), revela a parte feminina que todo homem possui e 
que, temida, deve ser mantida sempre à distância. E Loraux (1989, p.18) assevera: "Mais classicamente feminina que o gozo é a dor. [...] a virilidade exige a provação heroica do sofrimento [...]". Finalmente, a reclusão de Héracles ao interior da casa e o ato de cobrir o rosto com o peplo. Loraux nos informa que este, ao contrário do Khiton, era a túnica feminina por excelência. Segundo a autora, representar um homem, viril, vestido com um peplo, longe de indicar uma pretensa feminização, é apontar para sua segunda natureza, isto é, o feminino que nele habita. A recorrência ao feminino, simbolizado tanto pelo peplo quanto pelos banhos quentes, seria o modo pelo qual os gregos apontavam para a necessidade de equilíbrio entre masculinidade e feminilidade no próprio homem. Acerca disso, as palavras de Loreaux (1989) são esclarecedoras:

\begin{abstract}
Porque uma demasiada virilidade expõe permanentemente sua força à ameaça de esgotamento, convém que Héracles encontre periodicamente uma medida mais justa da energia viril. Para esse herói ambivalente um tal equilíbrio - sempre instável - só é obtido sob a condição de anular um excesso por outro, opondo um acréscimo de feminilidade a uma excessiva virilidade. Vemos que em Héracles a parte feminina é essencial, no que ela contribui para mantê-lo dentro do limite humano da virilidade. Vestido com uma mulher, submetido a um regime feminino, Héracles só faz assumir ainda melhor a figura humana do herói viril (p.158-159).
\end{abstract}

Também o modo pelo qual Héracles morre, conforme o constatamos na tragédia de Sófocles (497-406 a.C./2009) antes mencionada, é reveladora dessa vivência do feminino no corpo. Na referida peça teatral, Héracles se suicida por não suportar os sofrimentos de que vem a padecer ao vestir o peplo envenenado com o qual Dejanira, sua esposa, Ihe presenteia. Na verdade, Dejanira age movida pelo ciúme, uma vez que chegam em sua casa, a mando de Héracles, algumas mulheres, prêmios de guerra, dentre as quais, Íole, que havia conquistado o coração do herói. A esposa traída idealiza preparar um feitiço para fazer com que seu marido não tenha olhos senão para ela. Contudo, ao conversar com Nesso, o centauro vencido por Héracles, recebe daquele um pouco de seu sangue, acreditando tratar-se, conforme suas instruções, da desejada magia. Embebe o peplo destinado a Héracles com o sangue do centauro - que nada mais era que um poderoso veneno - e o faz chegar ao herói. Ao vesti-lo, ele passa a experimentar indescritíveis padecimentos que dilaceram seu corpo e o leva a suplicar a morte. É durante tal agonia que vemos Héracles se referir à dor, ao pranto e à morte, causada por uma mulher, como algo incompatível com sua virilidade. Assim ele se expressa:

Psicanálise \& Barroco em revista | v.17, n. 3 | dezembro de 2019 
[...]tenho o corpo todo devastado cativo deste entrave inexplicável... e não foi lança em luta na planície que o fez, nem a terrigênita tropa de Gigantes, nem a brutalidade monstruosa, nem gregos, nem bárbaros, nenhuma terra que purguei: mera mulher, femínea, não viril por natureza, sozinha me abateu, sem gláudio (versos 1056-1063).

E dirigindo-se ao filho, suplicando-Ihe que Ihe traga Dejanira para dela se vingar, ele grita:

\author{
[...]Tem dó de mim, \\ digno de dó para muitos, que como uma moça \\ berro em prantos - e isto ninguém \\ pode afirmar jamais me ter visto fazer: \\ sempre segui meus males ingemente. \\ Mas eu, que era tal, me revelo agora pobre fêmea! (versos 1070-1075)
}

Para encerrarmos essas breves considerações acerca da relação do viril com a feminilidade, encarnada em Héracles, devemos nos reportar a outro elemento que Loreaux (1989) destaca em sua análise sobre o homem grego e o feminino: a submissão à mulher. Para tanto, seguiremos os comentários que a autora realiza em torno da relação entre Héracles e a rainha da Lídia, Omphale. Interessante notar, de passagem, que o termo Omphalós serve para designar o cordão umbilical.

Obrigado pelo Oráculo de Delfos a se vender como escravo para a rainha Omphale, a fim de pagar pelo assassinato de Iphitos, Héracles se dirige à Lídia. Lá vive por três anos como escravo de Omphale que se apossa de sua clava e veste sua pele de leão, ordenando-Ihe que passasse a usar o peplo e a mitra (essencialmente feminina) e fiasse a lã a seus pés. Essa cena ficou imortalizada em telas de diversos artistas, dentre as quais podemos citar a de Jean-François Lemoyne e a de Peter Paul Rubens ambas expostas no Museu do Louvre, em Paris.

Conforme nos informa Loreaux (1989), alguns estudiosos da mitologia grega defensores ferrenhos da virilidade de Héracles, ao comentarem o referido episódio da vida do herói, procuram dar mais ênfase à sua servidão em relação à Omphale, ao fato dele estar ferido pelo amor, que ao fato do travestismo. Mas este último, como já assinalamos, não implica a feminização de Héracles. Prova disso é que mesmo durante seu cativeiro e sua submissão a Omphale, ele realiza proezas dignas de sua condição hiperviril, como libertar o reino do ataque de monstros diversos. Temos, pois, 
um homem viril que a despeito de sua condição servil em relação a uma mulher que o obriga mesmo a vestir-se em trajes femininos e a fiar a lã, não perde por isso sua masculinidade. Aliás, em algumas versões, é justamente pelas demonstrações de sua força viril que Héracles conquista Omphale.

O que nos parece importante a reter desse percurso pelo modo como os gregos pensavam a masculinidade e a feminilidade e, em especial, pelo tratamento que deram ao mais viril dos heróis, é o convite a uma reflexão acerca de uma concepção de masculinidade que não exclui o feminino ou mesmo algum aspecto culturalmente associado à feminilidade.

Nesse aspecto, não apenas as operações de combinação e inversão, através das quais o pensamento grego concebia o masculino e o feminino; mas também as diversas transfigurações que Héracles sofreu ao longo da tradição grega, da epopeia à tragédia, nos parecem apontar para uma masculinidade que não entra em oposição ao campo culturalmente adstrito à mulher, mas pode absorver algo dele, denotando, assim, a ambivalência que constitui o viril. Um homem capaz de preservar sua masculinidade a despeito de eventuais incursões que venha a fazer no universo de atributos associados à feminilidade.

Com Eurípedes, temos um Héracles cuja virilidade não é mais associada à violência, inclusive sexual, ao conquistador implacável de homens e mulheres, ao amante insaciável, possuidor de invejável potência fálica - capaz de possuir cinquenta virgens em uma só noite - e ao guerreiro imbatível. Agora, temos um Héracles que se dedica à vida doméstica, à companhia de uma mulher a quem é fiel e que, dentre tantas possíveis, ele escolheu para que lhe desse filhos, dos quais é um pai cuidadoso e amoroso. Trata-se aí, entendemos, de um Héracles decaído do lugar de exceção em relação aos demais homens, que decide agora não ser mais um "ao menos um" para ser apenas mais um homem, mais um pai. O fato é que, mesmo se levarmos em conta as diferentes versões e as várias transformações relativas à figura de Héracles, podemos identificar que sua vulnerabilidade, sua fragilidade, isto é, aquilo que para os gregos estaria associado ao feminino, não deixa de comparecer. É dessa combinação que, segundo nos lembra Loreaux (1989), o homem grego busca realçar o poder de sua virilidade. 
Por fim, levantamos a hipótese de que o deslocamento que Eurípedes opera na figura do Héracles consagrado na tradição é bastante pertinente para uma reflexão sobre as próprias mudanças que a masculinidade sofre ao longo da história. Tais transformações denunciam o caráter instável e frágil da virilidade, de resto já nuançado pelo tratamento que os gregos dispensaram à figura de heróis como Héracles. Instabilidade e fragilidade sobre a qual não apenas a antropologia e a sociologia, mas a psicanálise, podem lançar alguma luz. Queremos dizer com isso que, se os acontecimentos sociais e políticos têm relevância para a eclosão das chamadas crises da masculinidade, talvez seja porque haveria algo inerente ao próprio tornar-se homem que demandaria um trabalho relativamente constante de ressignificação do que é um homem.

A referida crise, se ela pode ser entendida como um fenômeno cultural, momento de perda dos referenciais simbólicos da masculinidade em cada época histórica, relaciona-se também com o modo pelo qual cada homem lida com o horror e a atração que o feminino lhe desperta. Desse ponto de vista, parece-nos que a masculinidade está sempre sujeita a crises, a reformulações e deslocamentos.

\section{Considerações FinaIS}

A época atual testemunha a expressão cada vez diversificada da bissexualidade psíquica, constitutiva do humano enquanto ser de linguagem, inapelavelmente separado da ordem natural do instinto. A organização fálica patriarcal experimenta um declínio, que se desenvolve em paralelo com a proliferação de diferentes modos de expressão do feminino na cultura, sobretudo da feminilidade. $O$ desencadeamento do ódio e da violência contra as mulheres e a chamada população LGBT, que tal configuração social parece provocar, evidencia a enorme dificuldade que grande número de homens revelam ter em lidar, por meio do simbólico, com a angústia de feminização que lhes atinge desde o mais íntimo de sua vida psíquica. Com efeito, através da psicanálise, nos parece possível pensar que o ódio ao feminino é inseparável do horror à castração que ele provoca nos homens; e denuncia, sem que estes o saibam, seu desejo pelo pai. 
A angústia, pois, está associada ao desejo de ser a causa do desejo do pai, o que, na fantasia, equivale a ser castrado, como uma mulher; tal qual esta última é imaginada nas teorias sexuais infantis. Eis aí o fantasma que assombra os homens desde tempos imemoriais: para ser um homem de verdade é preciso recalcar e repudiar sem trégua a feminilidade, inconscientemente desejada e sempre disposta a retornar.

Esse repúdio denuncia a crença dos homens em uma masculinidade ideal, purificada de qualquer traço do que cada época e cada um, na singularidade de sua fantasia, associa à feminilidade. Se isso fosse possível, teríamos um homem movido por uma pura atividade, invulnerável, capaz de exercer seu desejo desenfreado de dominação sobre todas as mulheres e todos os homens, subjugando-os a seu gozo. Em suma: um homem que não estaria submetido à castração. Deste, como vimos, nem o deus Priapo, nem o grande Héracles, conseguiram estar à altura. Do gozo desse supermacho - não diríamos nem super-homem, pois este sempre teve sua criptonita - cada homem está sempre aquém. Castrados de semelhante gozo, só lhes restam um gozo descontínuo, parcial; gozo do órgão, de um órgão sempre sujeito a falhas, muitas vezes insubordinado aos comandos de seu proprietário. Um órgão que também ele não está à altura daquele de Priapo, o que significa que, embora os homens construam sua masculinidade acreditando no contrário, o órgão não é o falo.

Acreditamos que o declínio do falicismo patriarcal revela a inadequação de Priapo - daquele apotropaico, protetor dos bens, dos objetos de gozo de seu dono quanto a seguir sustentando os ideais e os semblantes de um modelo de masculinidade mais e mais questionado e combatido. Será que não estamos testemunhando uma época em que se abre para os devotos de Priapo, uma aproximação também com Dioniso? Não seria possível pensarmos uma masculinidade mais livre em relação às amarras fálicas? A tão discutida e discutível "crise da masculinidade" não constituiria uma oportunidade para que, ao menos alguns homens, possam gozar da feminilidade e do feminino sem precisar se amarrar tão radicalmente ao mastro fálico, tal qual Ulisses ante as sirenes?

Finalmente, gostaríamos de pontuar que se de um lado o declínio do patriarcado e do falocentrismo que ele comporta é causa de mal-estar na cultura, por outro, ele convida os homens a fazer algo com essa nova configuração cultural; que 
se expressa na perda de referenciais simbólicos longa e fortemente enraizados na constituição da masculinidade ocidental. Se nós, homens, pudermos ao menos rir dessa detumescência do falicismo na cultura atual, já seria um grande feito, talvez heroico... 


\section{REFERÊNCIAS:}

ARROWSMITH, W. Introdução ao Héracles. In: EURÍPEDES. Héracles. Tradução, posfácio e notas: Trajano Vieira. São Paulo: Ed. 34, 2014.

ASSOUN, Paul-Laurent. Lecciones psicoanalíticas sobre masculino y femenino. Buenos Aires: Nueva Visión, 2006.

BRANDÃO, J. Mitologia Grega. 5ª ed. Petrópolis, RJ: Vozes, 1992.Vol. II.

DANIÉLOU, A. Le Phallus. Pardès: Puisseaux, 1993.

DENISE, M. Nos meandros do continente negro: questões sobre a homossexualidade feminina. In: QUINET, A.; JORGE, M.A.C. (Orgs). As homossexualidades na psicanálise: na história de sua despatologização. São Paulo: Segmento Farma, 2013.

DUPUIS, J. Em nome do pai: uma história da paternidade. São Paulo: Martins Fontes, 1989. EURÍPEDES. Héracles. Tradução, posfácio e notas: Trajano Vieira. São Paulo: Ed. 34, 2014. FREUD, S. Obras Completas. $4^{\mathrm{a}}$ ed. Madrid: Biblioteca Nueva,1981.

. (1908) Fantasias histericas y su relación con la bissexualidade. Tomo II.

. (1914) Introductión al narcisismo. Tomo II.

. (1915) Los instintos y sus vicissitudes. Tomo II.

. (1922) La cabeza de Medusa. Tomo III.

. (1923) El yo y el ello. Tomo III.

. (1924) La disolución del complejo de Edipo.Tomo III.

. (1925) Algunas consecuencias psíquicas de la diferencia sexual anatómica. Tomo

III.

. (1931) Sobre la sexualidad feminina. Tomo III.

(1933) Nuevas lecciones introductórias al psicoanálisis Lección XXXIII: La Feminidad.

HÉRITIER, F. Masculin/Féminin II: dissoudre la hiérarchie. Paris: Odile Jacob, 2012.

LACAN, J. (1957-1958). O seminário livro 5: As formações do inconsciente. Rio de Janeiro: Jorge Zahar Editor, 1999.

LOREAUX, N. Les expériences de Tirésias: le féminin et l'homme grec. Paris: Galimard, 1989. OLIVA NETO, J.A. Falo no jardim: priapéia grega, priapéia latina. Campinas, SP: Editora da Unicamp, 2006.

PFAUWADEL, A. Virilités plurielles. La cause du désir. Paris, n. 95, p. 5-6, 2017.

POMMIER, G. Féminin, révolution sans fin. Paris: Pauvert, 2016. 
SÓFOCLES. As traquínias. Apresentação, tradução e comentário filológico: Flávio Ribeiro de Oliveira. Campinas, SP: Editora da Unicamp, 2009.

VIGARELLO, G. A virilidade moderna: convicções e questionamentos. In: CORBIN, A; COURTINE, J-J; VIGARELLO, G. (Orgs.). História da virilidade - a invenção da virilidade. Da Antiguidade às Luzes. Petrópolis, RJ: Vozes, 2013. 


\title{
Between Priapus And Dionysus: Reflections ON THE MASCULINITY
}

\begin{abstract}
On the way to masculinity, the boy must overcome the feminine position in relation to the father, which implies castration as a premise. The repression of this desiring position returns in culture through the hatred of women and every subject supposed to incarnate the feminine. The latter's advance in culture, together with the decline of patriarchal referents, represents for men a threat to masculinity. A dilemma is insinuated: to appeal to Priapo, the itifalic god, or to approach Dionysus, that is, the feminine. This article discusses these two positions in the light of psychoanalysis and the Greek theater, especially of the figure of Heracles, symbol of hypermasculinity

KEYWORDS: Psychoanalysis; Masculinity; Femininity; Priapus; Dionísio.
\end{abstract}




\section{Entre Priape Et Dionysos : Réflexions SUR LA MASCULINITÉ}

\section{RÉSUMÉ}

Sur le chemin menant à la masculinité, le garçon doit surmonter la position féminine par rapport au père, ce qui implique la castration comme prémisse. Le refoulement de cette position désirante fait retour dans la culture par la haine contre des femmes et des sujets censés incarner le féminin. L'avancement culturel de ce dernier comme le déclin des référents patriarcaux constituent pour les hommes une menace à la masculinité. Un dilemme s'insinue: recourir à Priapo, le dieu ityphallique, ou s'approcher de Dionysos, soit du féminin. Cet article traite de ces deux positions à la lumière de la psychanalyse et du théâtre grec, en particulier de la figure d'Héraclès, symbole de l'hypermasculinité.

MotS-CLÉs: Psychanalyse, Masculinité, Féminité; Priapus; Dionísio. 
Entre Príapo E Dioniso: RefleXões Sobre A Masculinidade

RECEBIDO EM 02-07-2019

APROVADO EM 25-10-2019

(C) 2019 Psicanálise \& Barroco em revista

http://www.seer.unirio.br/index.php/psicanalise-barroco/index

revista@psicanaliseebarroco.pro.br

Programa de Pós-Graduação em Memória Social — UNIRIO

Memória, Subjetividade e Criação

www.memoriasocial.pro.br/proposta-area.php 